\title{
Rule of law in Greece buckles under institutionalised ill- treatment by law enforcement agents
}

VB verfassungsblog.de/rule-of-law-in-greece-buckles-under-institutionalised-ill-treatment-by-law-enforcementagents/

\section{Nikolaos Sitaropoulos Di 15 Mrz 2016}

The latest report on Greece by the Council of Europe anti-torture Committee (CPT), issued on 1 March, rang, once again, the alarm concerning decades-old, institutionalised, unlawful violence by law enforcement agents. In its press release CPT highlighted the need for Greece to fully acknowledge the phenomenon of police illtreatment and to adopt a "comprehensive strategy and determined action" to address it.

The issue is compounded by the fact that this deeply ingrained violence is combined with institutionalised racism inside parts of the Greek law enforcement forces, thus targeting in particular migrants. In its 2015 report the Greek Racist Violence Recording Network noted that in 21 out of the 81 racist incidents that were recorded in 2014 the perpetrators were either only law enforcement officials or law enforcement officials along with other perpetrators. Out of these, 13 took place in public places, six in police stations or detention centres, and two in an abandoned private place.

These findings were corroborated by the 2016 CPT report where it is noted that infliction of ill-treatment by law enforcement agents, particularly against foreign nationals, including for the purpose of obtaining confessions, continues to be a frequent practice. The report contains some particularly worrying, graphic paragraphs and an appended photograph concerning the alleged use in 2015 by the police in Thessaloniki of wooden bats during the interrogation of a Bulgarian national who was detained on remand.

The CPT report is alarming because it clearly identifies a Greek police culture under which it is not unprofessional to resort to ill-treatment, although its prohibition is enshrined in the unqualified and non-derogable Article 3 of the European Convention on Human Rights (ECHR). As the Strasbourg Court has underlined on numerous occasions (see e.g. Galotskin v. Greece, 2010) Article 3 ECHR enshrines one of the most fundamental values of democratic societies. Even in the most difficult circumstances, such as the fight against terrorism and organised crime, the Convention prohibits in absolute terms torture and inhuman or degrading treatment or punishment, irrespective of the victim's conduct. In addition, the Court has noted that in respect of a person deprived of their liberty, recourse to physical force which has not been made strictly necessary by their own conduct diminishes human dignity and is in principle an infringement of Article 3 ECHR.

One of the major root causes for this highly problematic situation lies with the culture of impunity that pervades parts of the Greek, primarily, police forces, as well as of prosecutorial and judicial authorities. This requires a drastic overhaul of the law enforcement overseeing and redress mechanisms and of the awareness-raising and sensitisation of all actors of the national justice system.

As regards the law enforcement sector, CPT recommends the fostering of proper conduct by police members towards detainees, notably by doing more to encourage police officers to prevent colleagues from ill-treating, and to report, through appropriate channels, all cases of violence by colleagues. Importantly, CPT underlines the need for the authorities to adopt "whistle-blower" protective measures. However, in order for these highly useful recommendations to be given effect it is necessary to develop a reporting system linked to an independent complaint authority and a legal and institutional system able to fully and effectively safeguard the whistle-blowers' personal security and other rights.

As regards the need to establish an independent and effective complaint mechanism, in his 2013 report on Greece, the Council of Europe Commissioner for Human Rights, drawing upon the Council of Europe Committee of Ministers Guidelines on eradicating impunity for serious human rights violations (2011), urged Greece to establish a fully independent and well-functioning complaints mechanism covering all law enforcement officials. This should be based on the five principles of effective complaints investigation: (a) independence: there should 
be no institutional or hierarchical connections between the investigators and the official complained against and there should be practical independence; (b) adequacy: the investigation should be capable of gathering evidence to determine whether the behaviour of the law enforcement body complained of was unlawful and to identify and punish those responsible; (c) promptness: the investigation should be conducted promptly and in an expeditious manner in order to maintain confidence in the rule of law; (d) public scrutiny: procedures and decision-making should be open and transparent in order to ensure accountability; and (e) victim involvement: the complainant should be involved in the complaints process in order to safeguard his or her legitimate interests.

What is however even more worrying and challenging is the fact that not only the administrative but also the judicial routes of investigation and prosecution in this context are fundamentally flawed. For example, CPT in its 2016 report refers to the cases of three migrant detainees whose allegations of torture and severe ill-treatment by police officers in 2013 were investigated by a public prosecutor. The prosecutor summarily dismissed the complaints and closed the file. The problem is that such bluntness has been encountered even at the highest judicial level, that of the Greek Court of Cassation (Areios Pagos). A characteristic example is the case of Kouidis v. Greece, where in 2006 the UN Human Rights Committee found the first violation by Greece of the International Covenant on Civil and Political Rights. This was the consequence of the fact that Areios Pagos, in a criminal case decided upon in 1998, did not take into account the applicant's claims that his confession to the police was given under duress (serious ill-treatment including the use of falanga) during his interrogation in the Athens police headquarters.

The above shows that international and European human rights norms and standards have not as yet been fully embedded in the Greek national legal system. As noted by Adamantia Pollis in her incisive study on human rights in modern Greece (1987), albeit the judiciary in this country has been structurally independent it has rarely acted as a separate and autonomous branch of government. This has been a consequence of an 'organic' conception of the Greek nation which is embodied in the state, and its institutions, reinforcing its power. Pollis' research in the 1980s demonstrated that Greek judges have remained committed to a legal philosophy that supports legal restrictions of rights in the name of higher state interests.

In order to overcome these structural shortcomings, the establishment of an effective system of administration of justice is needed, with courts empowered to apply domestic anti-torture law in line with the state's human rights obligations and international or regional case law. Under the Strasbourg Court's jurisprudence (see e.g. Gäfgen v. Germany, 2010) states have a positive procedural obligation, deriving from Article 3 ECHR, to conduct a thorough and effective investigation in all cases that raise an arguable claim of ill-treatment. This investigation should be capable of leading to the identification and punishment of those responsible. In view of this, in the course of the examination of all such cases the Strasbourg Court has imposed on itself the obligation to "apply a particularly thorough scrutiny". In fact, this is the level of scrutiny that is required also from prosecutors and courts at domestic level.

In the 1975 'first torturers' trial' in Greece targeting officers of the Greek military police (ESA) involved in torture during the 1967-1974 dictatorship (cf. Amnesty International's report), the court-martial prosecutor posed a fundamental question that is still echoing: "How could Greek officers sink to this moral degradation? Who are those responsible?" In a characteristically frank statement, probably prompted by the post-dictatorship atmosphere reigning then in Greece, the prosecutor added that "those morally responsible are not in this court. They are those who used the defendants... who, for many years, have given thousands of hours instruction on the fighting of communism without sparing even one hour to the defence of democracy".

Regrettably these phrases are still of relevance today and call for reflection. Unlawful violence and impunity in the Greek system of law enforcement are decades-old long and derive from a long, sad tradition of state repression and disregard of human dignity and civil rights. As Pollis said in her 1987 study, despite the post-1974 legal and institutional changes in Greece, the underlying world view of the earlier decades persists. This is why the 'culture' of impunity still constitutes the mind frame of many state institutions and is tolerated. It is indeed high time for the national authorities to cross the Rubicon and redress this situation where human rights standards and the rule of law cannot but buckle.

All views are strictly personal. 
LICENSED UNDER CC BY NC ND

SUGGESTED CITATION Sitaropoulos, Nikolaos: Rule of law in Greece buckles under institutionalised illtreatment by law enforcement agents, VerfBlog, 2016/3/15, http://verfassungsblog.de/rule-of-law-in-greecebuckles-under-institutionalised-ill-treatment-by-law-enforcement-agents/. 